\title{
Accumulation of Mineral Nutrients and Phytochemicals in Lettuce and Tomato Grown in High Tunnel and Open Field
}

\author{
Amanda Woolley ${ }^{1}$, Samuel Sumpter ${ }^{1}$, Myungjin Lee ${ }^{1}$, Jingwen $\mathrm{Xu}^{2}$, Shannon Barry ${ }^{1}$, \\ Weiqun Wang', C. B. Rajashekar ${ }^{1 *}$ \\ ${ }^{1}$ Department of Horticulture and Natural Resources, Kansas State University, Manhattan, KS, USA \\ ${ }^{2}$ Department of Food, Nutrition, Dietetics, and Health, Kansas State University, Manhattan, KS, USA \\ Email: crajashe@ksu.edu
}

How to cite this paper: Woolley, A., Sumpter, S., Lee, M., Xu, J.W., Barry, S., Wang, W.Q. and Rajashekar, C.B. (2019) Accumulation of Mineral Nutrients and Phytochemicals in Lettuce and Tomato Grown in High Tunnel and Open Field. American Journal of Plant Sciences, 10, 125-138.

https://doi.org/10.4236/ajps.2019.101011

Received: December 16, 2018

Accepted: January 15, 2019

Published: January 18, 2019

Copyright $\odot 2019$ by author(s) and Scientific Research Publishing Inc. This work is licensed under the Creative Commons Attribution International License (CC BY 4.0).

http://creativecommons.org/licenses/by/4.0/

\begin{abstract}
High tunnel production of horticultural food crops is becoming increasingly popular and has a significant impact on their growth, productivity and nutritional quality. The present study examines the effect of high tunnel production of lettuce (Lactuca sativa cv. "Two Star" and "New Red Fire") and tomato (Solanum lycopersicum cv. "Celebrity" and "Mountain Fresh") on their nutritional quality relating to major nutrients and health-promoting phytochemicals. High tunnel environment increased the concentration of $\mathrm{N}$ (protein) in both lettuce and tomato relative to the open field cultivation. The accumulation pattern of mineral nutrients in high tunnel was similar in green-leaf and red-leaf lettuce varieties. Lettuce varieties grown in high tunnel had higher accumulation of $\mathrm{C}, \mathrm{S}$ and $\mathrm{Zn}$ relative to those grown in open field. However, high tunnel environment suppressed the accumulation of many micronutrients such as $\mathrm{Mg}, \mathrm{Fe}, \mathrm{Cu}$ and $\mathrm{Mn}$ in both lettuce varieties but not in tomato. For example, accumulation of Fe was reduced by more than $80 \%$ in "Two Star" and by more than $55 \%$ in "New Red Fire" under high tunnel. It also suppressed the levels of many health-promoting phenolic compounds such as chlorogenic acid, chicoric acid, rutin and kaempferol in green-leaf lettuce and gallic acid in red-leaf lettuce. High tunnel environment improved the soil nutrient status but reduced the radiation levels (PAR, UV-A and UV-B) received by the crops. The results show that the high tunnel production has a significant impact on the nutritional quality relating to protein and mineral nutrients in both crops and health-promoting phytochemicals in lettuce.
\end{abstract}

\section{Keywords}

High Tunnel, Lettuce, Mineral Nutrients, Nutritional Quality, Phytochemicals, Tomato 


\section{Introduction}

High tunnel production of horticultural crops is increasingly becoming popular in the US because it can extend the growing season and lead to aesthetically better looking produce with greater consumer preference. High tunnels are passive protective structures that markedly alter the microclimate, soil characteristics and intensity and quality of light received by crops, which can impact both plant growth and its nutritional quality.

In spite of higher aesthetic appeal and often higher yields in high tunnels [1], little is known about nutritional quality of the produce. Many studies have reported that crops grown in high tunnel have reduced nutritional value, especially in relation to health-promoting phytochemicals compared to those grown in open field. Zhao et al. [1] examined the effect of growing green- and red-leaf lettuce in high tunnels on phenolic compound accumulation and found that it was suppressed in both green- and red-leaf lettuce varieties grown in high tunnels with more pronounced differences in the red-leaf lettuce variety. Similar results were observed in young green- and red-leaf lettuce varieties grown in high tunnels [2]. Furthermore, it is likely that greenhouse grown plants which typically receive reduced light intensity may also show similar results. Romani et al. [3] showed that lettuce grown in a greenhouse which received approximately $27 \%$ less light intensity than open field had reduced concentration of many individual polyphenols as well as the total phenolic compounds. Similarly, high tunnel cultivation of red raspberry resulted in reduced level of carotenoids including $\beta$-carotene, lutein and zeaxanthins in the fruits compared to open field culture [4].

The impact of high tunnel or protected environment production of food crops on the nutritional quality relating to major nutrients such as protein and mineral composition is not well understood. Protein and micronutrient deficiency is a serious challenge in public health, especially in the developing regions of the world. Many studies and the World Health Organization (WHO) have addressed protein and energy (calories) deficiencies together as they typically occur together in many countries afflicted with malnutrition [5]. It is estimated that about a third of world's population and $80 \%$ of the children in South Asia are affected by protein-energy deficiency [5]. It has a devastating impact on children as it affects their physical and mental development resulting in stunted growth and impaired cognitive development [5] [6]. The problem is likely to get worse as the global population is projected for a rapid growth in the coming decades, especially in developing countries [7].

Micronutrients include minerals essential for physical and mental development and to prevent diseases, and for the general wellbeing of humans. They are obtained through diet and are not produced in our body. Although they are needed in small quantities, their deficiency can lead to permanent disabilities, poor health and death, if not treated. Plant food is an important source of minerals for humans and their deficiency is a significant global health issue. The World Health Organization estimates that more than 2 billion people globally 
suffer from this. It is especially a major concern in young children as it can lead poor physical and mental development, negatively affecting their productivity, future potential and wellbeing including predisposition to or exacerbation of many illnesses and mental retardation [8] [9].

While there are some studies dealing with the effect of high tunnel production of horticultural food crops in relation to health-promoting phytochemicals, very little is known about its impact on major nutrients important for human health. In the present study, we investigate the effect of high tunnel production of commonly grown vegetables such as lettuce and tomato on their nutritional quality relating to both major mineral nutrients and health-promoting phytochemicals.

\section{Materials and Methods}

Seeds of lettuce (Lactuca sativa cv. "Two Star" and "New Red Fire") and tomato (Solanum lycopersicum cv, "Celebrity" and "Mountain Fresh") were germinated in plastic trays $(53 \mathrm{~cm} \times 27 \mathrm{~cm})$ containing Premier Promix soil medium in a growth chamber set at $22^{\circ} \mathrm{C}$ (day/night) and 8 h photoperiod with a photon flux of $300 \mu \mathrm{mol} / \mathrm{cm}^{2} / \mathrm{sec}$. After 4 weeks, seedlings were transplanted into pots $(10 \mathrm{~cm}$ $\times 10 \mathrm{~cm}$ ) containing Metromix 350 with 1 seedling/pot. Seedlings were transferred to a greenhouse maintained approximately at constant $22^{\circ} \mathrm{C}$ and grown for 2-3 weeks. Lettuce and tomato seedlings were watered daily before transplanting them to the field. Tomato seedlings were fertilized via irrigation once a week using Peat Lite (20-10-20) at $200 \mathrm{ppm}$ of N. The field experiments were conducted at the Willow Lake Horticulture Farm, Manhattan, KS from June $25^{\text {th }}$ through late September of 2016 and consisted of separate experimental plots in open field (OF) of and high tunnel (HT). The experimental plots were similar in size and adjacent to each other. The high tunnel $(14.6 \mathrm{~m} \times 9.4 \mathrm{~m})$ was covered with a single layer of 6 mil - 4 year UV clear polyethylene sheet (Hummert International, Topeka, KS). The sides of the high tunnel were kept open (about 1 $\mathrm{m}$ high) for air circulation and to prevent large air temperature differences between the inside and outside the high tunnel. The experiments were conducted using a completely randomized block design with 3 replications. Each replication consisted of 12 seedlings for each lettuce variety and 6 seedlings for each tomato variety. Seedlings were transplanted into the open field and high tunnel onto the raised beds covered with black plastic mulch (Harris Seeds, Rochester, NY) to reduce soil water loss and suppress weeds. For lettuce, the spacing between rows was $25 \mathrm{~cm}$ and $20 \mathrm{~cm}$ within rows, and for tomato it was $0.91 \mathrm{~m}$ both between and within rows. The crops were irrigated with drip-tape irrigation system as needed and were grown using the recommended management practices. After 1 - 2 weeks of transplanting, the crops were fertilized with Alaska Fish Fertilizer (5-1-1; Lily Miller Brands, Walnut Creek, CA) at a rate of 1 tbs/gal and Hi-Yield blood meal (Voluntary Purchasing Groups, Bonham, TX) at recommended levels for lettuce, and with Alaska Fish Fertilizer in the case of tomato. Both crops were treated with Natural Guard Crawling Insect Control containing 
diatomaceous earth (Voluntary Purchasing Groups, Inc. Bonham, TX) and liquid Thuricide at recommended doses to reduce pest incidence. Crop management practices followed for each crop in open field and in high tunnel were identical.

Daily weather data with regard to mean, maximum and minimum temperatures, precipitation, and solar radiation (data not presented) were collected during the growing season from the weather station located near the test plots, and complete weather data are archived at mesonet.ksu.edu (Rockyford, KS).

\subsection{Light Measurements}

Photon flux density of photosynthetically active radiation (PAR) was measured using Quantum Radiometer (LI-185B, Li-Cor, Lincoln, NE) in high tunnel and open field. UV-A and UV-B irradiance was measured using Research Radiometer (ILT-5000, International Light Technologies, Inc., Peabody, MA) around noon on a clear day (July 21st) when the annual total solar radiation was near the maximum level $\left(28.1 \mathrm{MJ} / \mathrm{m}^{2}\right)$. The sensors were placed on a flat surface at the canopy level to measure the radiation. Each plot was divided into 4 quadrants and one light measurement was made in each quadrant.

\subsection{Soil Nutrient Analyses}

After clearing the soil surface of plant debris and roots, one soil sample from each quadrant was collected from top 10 inch of soil in mid-season and mixed thoroughly to obtain a composite sample. The composite sample was used for analyzing for contents of organic matter, ammonium-N, nitrate- $\mathrm{N}$, phosphorus, potassium, calcium, copper, iron, magnesium, sulfur- $\mathrm{SO}_{4}$, manganese, iron and zinc. Total nitrogen was analyzed using LECO TrueSpec CN combustion analyzer. Extractable nitrate $\mathrm{N}$ and ammonium-N were extracted in $1 \mathrm{M} \mathrm{KCl}$ and assayed (cadmium reduction for nitrate- $\mathrm{N}$ and indophenol colorimetric method for ammonium-N) using Rapid Flow Analyzer (Model RFA-300-Alpkem Corp., Clackamas, OR). Total organic matter was measured using Walkley-Black method. Extractable cations ( $\mathrm{Ca}, \mathrm{K}$ and $\mathrm{Mg}$ ) were quantified using ammonium acetate extraction and other micronutrients $(\mathrm{Cu}, \mathrm{Fe}, \mathrm{S}, \mathrm{Mn}$ and $\mathrm{Zn})$ using an Inductively Coupled Plasma (ICP) Spectrometer (Model 720-ES ICP Optical Emission Spectrometer, Varian Australia Pty Ltd., Australia).

\subsection{Tissue Nutrient Analyses}

Lettuce leaf samples were collected at the time of harvest and oven dried at $75^{\circ} \mathrm{C}$ for 3 days. The samples were ground in an electric grinder before the nutrient analyses. Pericarp of fully ripe tomato fruits were separated and freeze-dried. The samples were ground into fine powder as outlined above before the analyses. Total carbon and nitrogen concentrations in tissue were assayed using a LECO TruSpec CN combustion analyzer and the protein contents were calculated according to Fujihara et al. [10]. The concentrations of phosphorus, potas- 
sium, calcium, copper, iron, magnesium, sulfur, manganese, iron and zinc were determined using perchloric digest method as outlined by Gieseking et al. [11]. The nutrient concentrations were quantified using an Inductively Coupled Plasma (ICP) Spectrometer (Model 720-ES ICP Optical Emission Spectrometer, Varian Australia Pty Ltd., Australia). All the soil and tissue analyses were conducted in the KSU Soil and Tissue Analysis Lab.

\subsection{Extraction of Phenolic Compounds}

Following chemicals and standards were used in quantifying the phenolic compounds; gallic acid (3,4,5-trihydroxybenzoic acid) and quercetin-3-rutinoside (rutin) (ACROS Organics, Morris Plains, NJ); chlorogenic acid, caffeic acid (3,4-hydroxy-cinnamic acid) and formic acid (Sigma Aldrich, St. Louis, MO); luteolin-7-glucoside and apigenin-7-glucoside (Indofine Chemical, Hillsborough, NJ); ethanol and HPLC grade solvents (Alfa Aesar, Ward Hill, MA, Thermo Fisher Scientific, Fair Lawn, NJ).

Freeze-dried and ground lettuce leaf samples $(0.15 \mathrm{~g})$ were extracted with 15 $\mathrm{ml}$ of $70 \%$ aqueous methanol containing flavone as an internal standard by vigorous agitation on an orbital shaker (Benchmark, Edison, NJ) overnight. The extract was centrifuged at $3950 \mathrm{rpm}$ for $30 \mathrm{~min}$ and then filtered to remove the cell debris. Aqueous methanol (70\%) was added to make up the final volume (25 $\mathrm{mL}$ ) and $2 \mathrm{~mL}$ of this was evaporated to dryness under streaming nitrogen gas. The residue was re-dissolved in $200 \mu \mathrm{L}$ of $70 \%$ methanol and then filtered using $0.45 \mu \mathrm{m}$ Whatman syringe (Corning Inc., Corning, NY) for HPLC analyses.

\subsection{Quantification of Phenolic Compounds}

The phenolic compounds in lettuce leaves quantified included gallic acid, chlorogenic acid, caffeic acid, chicoric acid, luteolin-7-glucoside, rutin, apigenin-7-glucoside and kaempferol. With regard to carotenoid profile for tomato, valid analyses and comparative examination could not be accomplished as the cultivars used in this study were indeterminate and identifying the same physiological maturity stage for fruits among different treatments was difficult. Hence we report here the phenolic profile for lettuce grown in open field and high tunnel. The phenolic compounds in lettuce were analyzed using a Shimadzu HPLC system (Kyoto, Japan), consisting of a DGU-20A3 degasser, a LC-20AB liquid delivery pump, a SIL-20ACHT auto-sampler and a CTO-20AC column oven along with a SPD-20A diode array detector. The phenolic compounds were separated using a C18 reversed phase column $(250 \mathrm{~mm} \mathrm{~L} \times 4.6 \mathrm{~mm} \mathrm{D}$, Waters, Milford, MA). The elution was performed with mobile phase A (5\% formic acid in deionized water) and mobile phase B (5\% formic acid in 95\% methanol) at a flow rate of $0.8 \mathrm{~mL} / \mathrm{min}$ and $31^{\circ} \mathrm{C}$ oven temperature. The gradient used for solvent $\mathrm{B}$ was $0 \%$ - 10\% for $5 \mathrm{~min}$. 10\% - $40 \%$ for $25 \mathrm{~min}, 40 \%$ - $70 \%$ for $10 \mathrm{~min}$ and held at $70 \%$ for 16 min before returning to $0 \%$. Phenolic compounds in samples were identified and quantified using UV/VIS scans from 190 to $800 \mathrm{~nm}$ with diode 
array detector using authentic standards. The data were analyzed using the Shimdzu LC Solution Software (Kyoto, Japan). Phenolic acids were expressed as equivalent of vanillic acid and flavonoids as equivalent of quercetin.

\subsection{Data Analyses}

The statistical differences in nutrients and phenolic compounds between open field and high tunnel were determined using ANOVA (SAS 9.4, Cary, NC and XLSTAT, Addinsoft, New York, NY) and the means were compared using Tukey's method at $\mathrm{p} \leq 0.05$ and $\mathrm{p} \leq 0.01$.

\section{Results and Discussion}

The maximum, minimum and average temperatures and the precipitation data during the growing season from mid-June to the end of October are shown in Figure 1. The differences in temperatures inside the tunnel and open field were insignificant (data not shown) because of the efficient air circulation in and out of the tunnel through the side vents. The plots in the open field and in high tunnel were irrigated regularly as needed to avoid water stress. The radiation inside the tunnel and open field was measured during mid-day (July $21^{\text {st }}$ ). The largest reduction in radiation inside the tunnel relative to open field was in UV-B $(\sim 46 \%)$, followed by UV-A ( 33\%) and PAR ( 17\%, Table 1$)$.
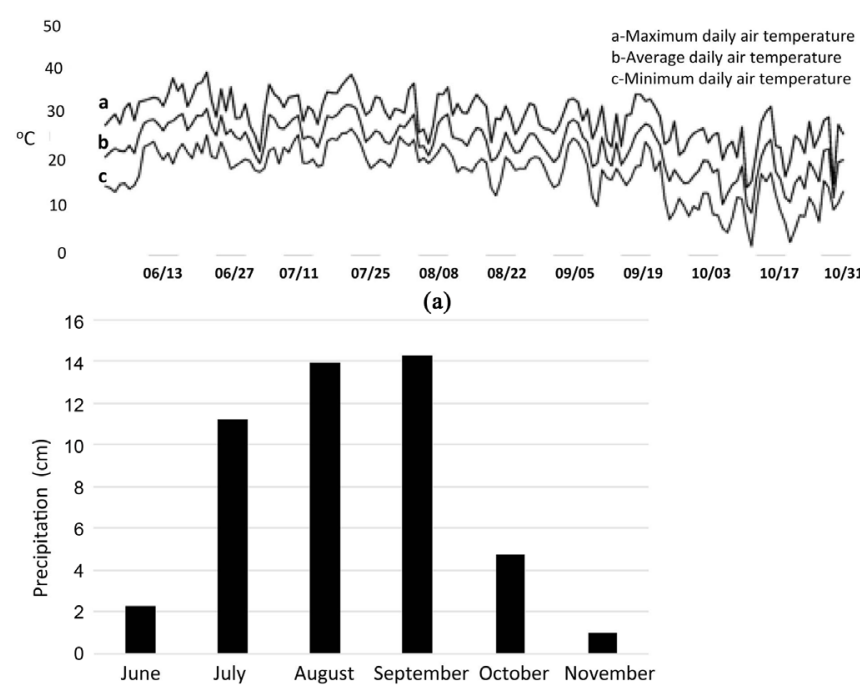

(b)

Figure 1. Maximum, average and minimum field air temperatures $\left({ }^{\circ} \mathrm{C}\right)(\mathrm{a})$ and monthly precipitation (cm) (b) during growing season in 2016.

Table 1. Radiation in open field and high tunnel measured on July $21^{\text {st }}, 2016$ around noon and percent reduction in radiation in high tunnel relative to the open field.

\begin{tabular}{cccc}
\hline Radiation & Open field & High tunnel & Percent reduction \\
\hline PAR & $1591.66 \mu \mathrm{E} / \mathrm{m}^{2} / \mathrm{s}$ & $1316.66 \mu \mathrm{E} / \mathrm{m}^{2} / \mathrm{s}$ & 17.27 \\
UV-A & $0.003 \mathrm{w} / \mathrm{cm}^{2}$ & $0.002 \mathrm{w} / \mathrm{cm}^{2}$ & 33.33 \\
UV-B & $0.00160 \mathrm{w} / \mathrm{cm}^{2}$ & $0.00085 \mathrm{w} / \mathrm{cm}^{2}$ & 46.87 \\
\hline
\end{tabular}


The growing conditions had significant impact on the nutritional quality of both lettuce and tomato. The changes with regard to the major nutrients in two lettuce varieties, a green, loose-leaf, "Two Star" and a red, loose-leaf, "New Red Fire", were, by and large, similar (Figure 2). Leaf concentrations of N, S and Zn were significantly higher in both varieties grown in high tunnel than those grown in open field. However, in "New Red Fire" under high tunnel, in addition to the above nutrients there was a significant increase in the accumulation of $\mathrm{P}$ compared to the open field (Figure 2). Concentrations of $\mathrm{K}$ and $\mathrm{Ca}$ in the leaves were not affected by the growing conditions in both varieties.

It is important to note that low $\mathrm{N}$ content in these lettuce varieties grown in open field indicates low protein content which has a special significance because protein is a major essential nutrient group in human diet and is often deficient in staple diets of a large portion of global population. The ultimate source of protein and amino acids for human body is through diet and plant food rich in protein plays a crucial role in supplying $\mathrm{N}$ needed for protein synthesis. Thus, sound strategies to improve $\mathrm{N}$ (protein) content in food would be central to tackling the global malnutrition which is expected to sharply increase with the projected increase in population growth especially in developing countries. Henchion et al. [12] reviewed the current and future demands of protein considering the projected population growth and offered different scenarios for meeting the demands with traditional and novel sources of protein. In our study,

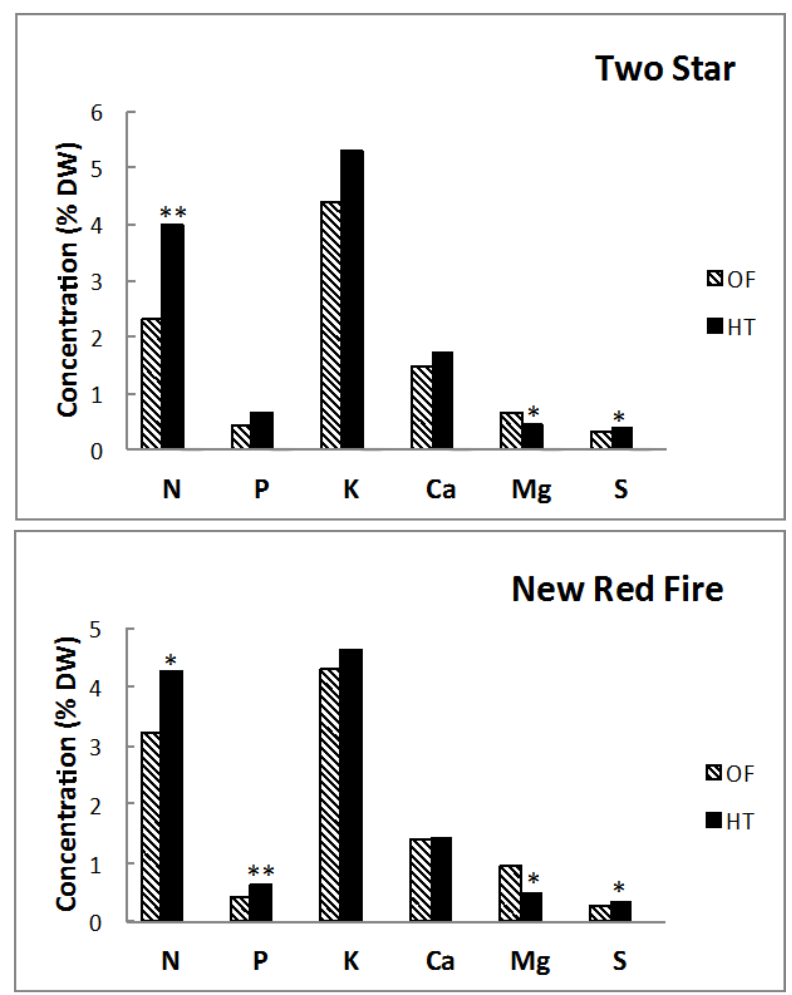

Figure 2. Leaf concentrations of nutrients as percent of dry weight in "Two star" and "New Red Fire" at the time of harvest. Significant differences between open field (OF) and high tunnel (HT) are indicated by ${ }^{*}$ and ${ }^{* *}$ at $\mathrm{p} \leq 0.05$ and $\mathrm{p} \leq 0.01$, respectively. 
protein levels in "Two Star" and "New Red Fire" increased significantly by growing them in high tunnel (Table 2). A large increase in $\mathrm{N}$ concentration, more than 50\% in "New Red Fire" and 70\% in "Two Star" grown in high tunnel, was observed (Figure 2 and Figure 3).

In lettuce, $\mathrm{C}$ accumulation was significantly higher under high tunnel. High tunnel condition increased C accumulation by $49 \%$ in "Two Star" and by $20 \%$ in "New Red Fire" relative to the open field (Figure 3). This was in spite of reduced PAR in high tunnel suggesting that other growing conditions may favor higher photosynthetic activity in the plants grown in high tunnel.

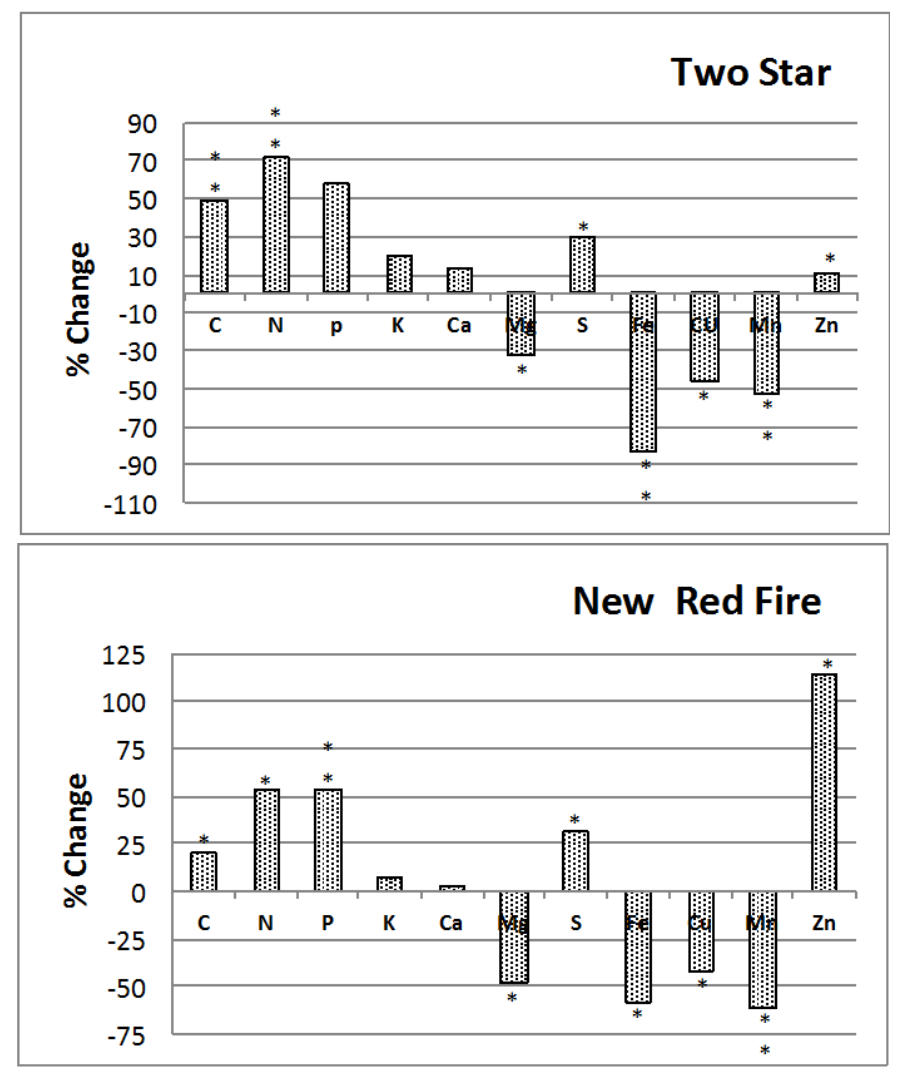

Figure 3. Percent change in leaf concentrations of nutrients in "Two star" and "New Red Fire" grown in high tunnel relative to those grown in open field. Significant differences between open field and high tunnel are indicated by ${ }^{*}$ and ${ }^{* *}$ at $p \leq 0.05$ and $p \leq 0.01$, respectively.

Table 2. Carbon, protein and mineral nutrient composition of lettuce cultivars grown in open field and high tunnel. Significant differences between open field and high tunnel are indicated by ${ }^{\star}$ and ${ }^{* *}$ at $\mathrm{p} \leq 0.05$ and $\mathrm{p} \leq 0.01$, respectively.

\begin{tabular}{cccccccc}
\hline & & Carbon (\%) & Protein (\%) & $\mathrm{Fe}(\mathrm{ppm})$ & $\mathrm{Cu}(\mathrm{ppm})$ & $\mathrm{Mn}(\mathrm{ppm})$ & $\mathrm{Zn}(\mathrm{ppm})$ \\
\hline \multirow{2}{*}{ Two Star } & OF & 25.1 & 12.4 & 6234.7 & 13.0 & 164.7 & 37.6 \\
& HT & $37.4^{* *}$ & $14.1^{\star}$ & $1057.0^{* *}$ & $6.9^{*}$ & $76.7^{* *}$ & $56.1^{\star}$ \\
New Red & OF & 30.1 & 17.2 & 6747.4 & 13.1 & 184.8 & 33.3 \\
Fire & HT & $36.2^{*}$ & $22.8^{\star}$ & $2770.4^{*}$ & $7.5^{*}$ & $72.9^{* *}$ & $71.2^{\star}$ \\
\hline
\end{tabular}


However, the concentrations of many minor mineral nutrients such as $\mathrm{Mg}, \mathrm{Fe}$, $\mathrm{Cu}$ and $\mathrm{Mn}$, with the exception of $\mathrm{S}$ and $\mathrm{Zn}$ were suppressed in both lettuce varieties grown in high tunnel compared to those grown in open field. The general trend of minor nutrient accumulation in high tunnel and open field was again similar in both varieties. However, the differences were notable between the varieties with regard the level of accumulation of some of these nutrients. The striking difference between the varieties was the accumulation of $\mathrm{Zn}$ under high tunnel. The Zn accumulation in "New Red Fire" more than doubled while it increased slightly, approximately by $10 \%$, in "Two Star" grown in high tunnel compared to those grown in open field. Like other micronutrient deficiency, the data on the prevalence of $\mathrm{Zn}$ deficiency is not fully documented. Wessells and Brown [13] predicted, based on the available $\mathrm{Zn}$ in food consumed in several regions of the world and the possible symptoms of $\mathrm{Zn}$, that more than $17 \%$ of the global population is at risk of $\mathrm{Zn}$ deficiency, and it is especially common in Sub-Saharan Africa and South Asia.

In addition, Fe and Mn uptake was markedly suppressed under high tunnel, by more than $80 \%$ in "Two Star" and by more than $55 \%$ in "New Red Fire" for Fe, and by more than $50 \%$ in both "Two Star" and "New Red Fire" for Mn. The deficiency of $\mathrm{Fe}$ is considered a major part of malnutrition throughout the world, nearly 2 billion people worldwide suffer from Fe deficiency [14] which can lead to anemia and other major health issues [15] [16]. It is especially a serious problem in pregnant women in many countries, accounting for nearly $20 \%$ in North America and is as high as $50 \%$ in South Asia and Sub-Saharan Africa [9]. Therefore, open field cultivation of lettuce has the potential to mitigate the Fe and Mn deficiency problems in our diets.

In the case of tomato fruits as in lettuce, $\mathrm{N}$ (protein) concentration increased in both "Celebrity" and "Mountain Fresh" grown in high tunnel compared to those grown in open field (Figure 4). The increase in $\mathrm{N}$ content ranged from about $47 \%$ in "Mountain Fresh" to $51 \%$ in "Celebrity". In addition, fruits from only "Celebrity" grown in high tunnel had higher $\mathrm{Zn}$ concentration than those from the open field. However, there were no significant differences in other nutrients between the fruits of both varieties grown in high tunnel and open field (Table 3). Thus, growing both varieties of lettuce and tomato in high tunnel has a distinct advantage in that the there is a significant improvement in the protein concentration of the edible parts of these crops (Table 2 and Table 3 ).

The data on the soil nutrient and organic matter status in high tunnel and open field are presented in Table 4. The status of most of nutrients and organic matter was better in high tunnel compared to open field. With the exception $\mathrm{NH}_{4}-\mathrm{N}$ and $\mathrm{Cu}$, there were significant differences in the contents of all nutrients between high tunnel and open field. However, soil $\mathrm{NO}_{3}-\mathrm{N}$ content was significantly higher in high tunnel relative to that in open field. The results from this study that the general nutrient status of soil in high tunnel is higher than in open field is consistent with previous studies that showed that high tunnels modify the soil health with typically higher organic matter in high tunnels than 


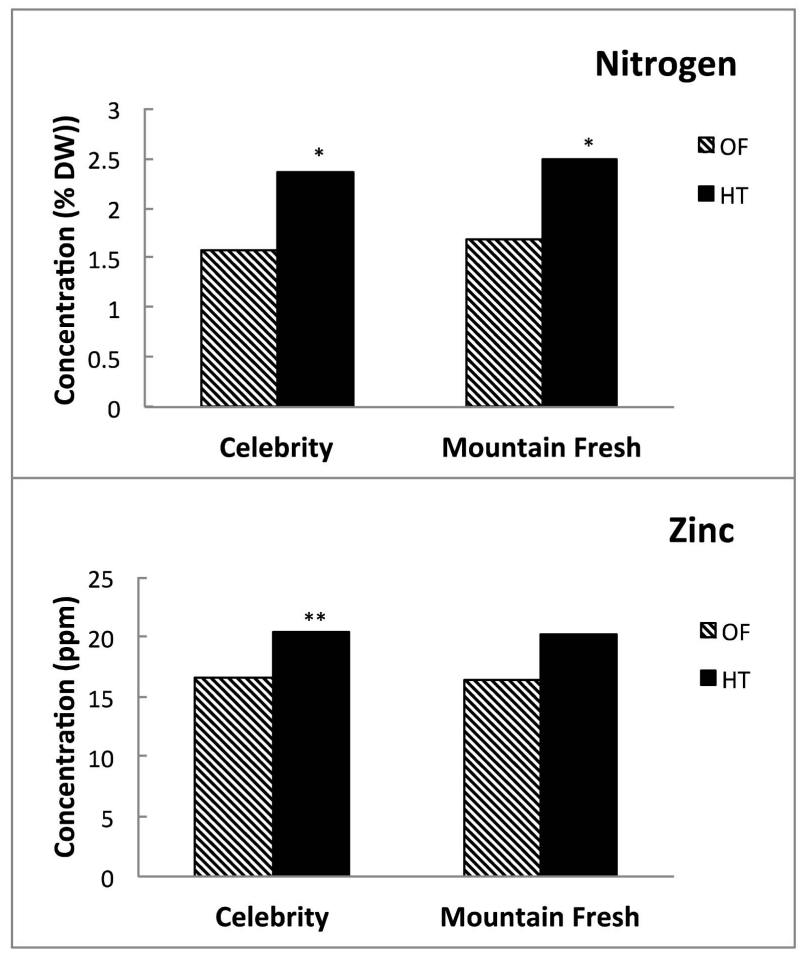

Figure 4. Leaf nitrogen and zinc concentrations (ppm) in tomato fruits "Celebrity" and "Mountain Fresh" grown in open field and high tunnel. Significant differences between open field and high tunnel are indicated by ${ }^{*}$ and ${ }^{* *}$ at $\mathrm{p} \leq 0.05$ and $\mathrm{p} \leq 0.01$, respectively.

Table 3. Mineral and protein composition of tomato fruits grown in open field and high tunnel on dry weight basis. Significant differences between open field and high tunnel are indicated by ${ }^{*}$ at $\mathrm{p} \leq 0.05$ and non-significance by NS.

\begin{tabular}{|c|c|c|c|c|c|c|c|c|c|c|c|}
\hline \multicolumn{12}{|c|}{ Nutrients } \\
\hline & & Carbon (\%) & Protein (\%) & $\mathrm{P}(\%)$ & K (\%) & $\mathrm{Ca}(\%)$ & $\operatorname{Mg}(\%)$ & S (\%) & $\begin{array}{c}\mathrm{Fe} \\
(\mathrm{ppm})\end{array}$ & $\begin{array}{c}\mathrm{Mn} \\
(\mathrm{ppm})\end{array}$ & $\begin{array}{c}\mathrm{Cu} \\
(\mathrm{ppm})\end{array}$ \\
\hline \multirow{3}{*}{ Celebrity } & $\mathrm{OF}$ & 35.36 & 10.4 & 0.45 & 3.45 & 0.19 & 0.16 & 0.17 & 37.50 & 7.33 & 6.63 \\
\hline & $\mathrm{HT}$ & 34.36 & 15.7 & 0.45 & 3.57 & 0.14 & 0.15 & 0.18 & 50.00 & 7.33 & 6.70 \\
\hline & & NS & * & NS & NS & NS & NS & NS & NS & NS & NS \\
\hline \multirow{3}{*}{$\begin{array}{c}\text { Mountain } \\
\text { Fresh }\end{array}$} & OF & 34.90 & 11.2 & 0.43 & 3.32 & 0.19 & 0.15 & 0.18 & 34.90 & 6.77 & 5.90 \\
\hline & $\mathrm{HT}$ & 35.18 & 16.5 & 0.43 & 3.48 & 0.22 & 0.16 & 0.18 & 54.46 & 8.57 & 6.30 \\
\hline & & NS & * & NS & NS & NS & NS & NS & NS & NS & NS \\
\hline
\end{tabular}

Table 4. Soil nutrients and organic matter (\%) in open field and high tunnel. All nutrients are in ppm. Significant differences between open field and high tunnel are indicated by ${ }^{*}$ and ${ }^{* *}$ at $\mathrm{p} \leq 0.05$ and $\mathrm{p} \leq 0.01$, respectively and non-significance by NS.

\begin{tabular}{ccccccccccccc}
\hline & $\mathrm{OM}(\%)$ & $\mathrm{NH}_{4}-\mathrm{N}$ & $\mathrm{NO}_{3}-\mathrm{N}$ & $\mathrm{P}$ & $\mathrm{K}$ & $\mathrm{Ca}$ & $\mathrm{Mg}$ & $\mathrm{Cu}$ & $\mathrm{Fe}$ & $\mathrm{Mn}$ & $\mathrm{Zn}$ \\
\hline $\begin{array}{c}\text { Open } \\
\text { field }\end{array}$ & 2.44 & 11.06 & 5.57 & 81.86 & 320.13 & 2183.43 & 348.85 & 0.96 & 30.76 & 12.14 & 1.40 \\
$\begin{array}{c}\text { High } \\
\text { tunnel }\end{array}$ & 6.08 & 17.27 & 30.28 & 493.83 & 821.68 & 3109.83 & 393.96 & 1.03 & 41.14 & 21.89 & 15.63 \\
& $* *$ & $\mathrm{NS}$ & $*$ & $* *$ & $* *$ & $* *$ & $*$ & $\mathrm{NS}$ & $*$ & $* *$ & $* *$ \\
\hline
\end{tabular}


in open field (Fitzgerald and Hutton [17]. The study also found that the established high tunnels tend to accumulate more $\mathrm{P}$ and lower $\mathrm{K}$ levels compared to newly established high tunnels. Similar results were reported by Knewston et al. [18] who found that organic matter carbon was higher in high tunnels especially with organic management perhaps resulting from a slower decomposition of organic matter in high tunnels relative to open field.

Thus, from the data on the nutrient status of plants, one would assume that the higher accumulations of certain nutrients in lettuce and tomato is a reflection of the better soil nutrient status in high tunnel, however, this assumption is not supported by the fact that many nutrient levels in leaves of lettuce grown in high tunnel were lower ( $\mathrm{Mg}, \mathrm{Fe}, \mathrm{Cu}$ and $\mathrm{Mn}$ ) compared to those in plants grown in open field although the levels of these soil nutrients was significantly higher in high tunnel than in the open field. In addition, there was no significant difference in most nutrients except $\mathrm{N}$ and $\mathrm{Zn}$ (only in celebrity) in tomato fruits despite the differences in soil nutrient levels between high tunnel and open field. Thus, the changes in the nutrient levels in edible parts of these crops suggest that they are not a reflection of the soil nutrient status but it may be a result of interactions of many other factors associated with variable growing conditions associated with high tunnel and open field.

With regard to health-promoting phytochemicals, a number of phenolic acids and flavonoids were measured in lettuce varieties at the time of harvest. The results were variable with regard to varieties and the phytochemicals. A typical HPLC profile of phenolic compounds for "Two Star" grown in high tunnel and open field is presented in Figure 5.
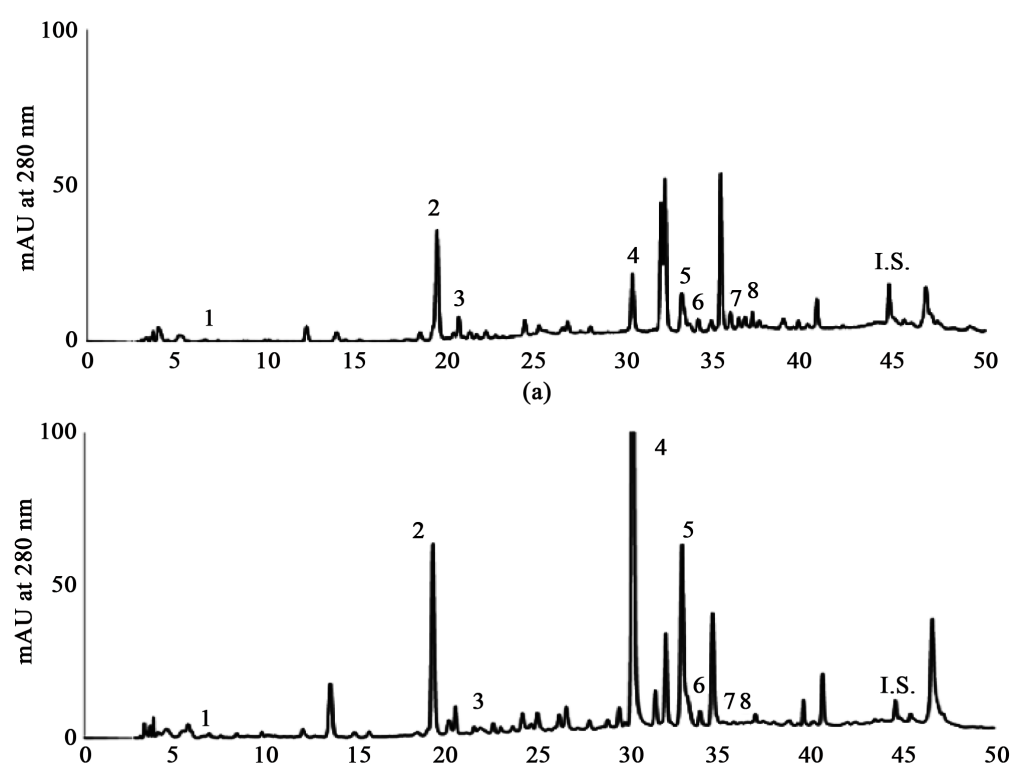

(b)

Figure 5. HPLC chromatograms of phenolic compounds in leaves of "Two star" grown in high tunnel (a) and open field (b). Peak 1-gallic acid, peak 2-chlorogenic acid, peak 3-caffeic acid, peak 4-chicoric acid, peak 5-luteolin-7-glucoside, peak 6-rutin, peak 7-apigenin-7-glucoside, peak 8-kaempferol and I. S.-flavone. 
"Two Star" grown in open field had much higher concentration of many phenolic compounds than that grown in high tunnel. Plants grown in open field had significantly higher leaf concentration of chlorogenic acid, chicoric acid and luteolin-7-glucoside compared to those grown in high tunnel (Figure 6). Open field conditions increased concentrations of chicoric acid by more than 12 -fold, luteolin-7-glucoside by more than 4-fold and chlorogenic acid by nearly 3 -fold in the leaves of "Two Star." However, no significant differences were observed in gallic acid, caffeic acid and apigenin-7-glucoside between open field and high tunnel. The higher accumulation of phenolic compounds in lettuce ("Two Star") is consistent with the previous study by Oh et al. [2] who found that the concentrations of major phenolic compounds in lettuce, namely chlorogenic acid and chicoric acid, were significantly higher in both green-leaf and red-leaf cultivars including the total phenolic content and the antioxidant capacity during early stages of plant growth in open field. Zhao et al. [1] found similar results in which concentrations of chlorogenic acid and many flavonoids were higher in both green-and red leaf lettuce grown in open field but the response was variable depending on the season. Furthermore, high tunnel production was found to lower the antioxidant capacity in pacchoi and spinach grown in high tunnels [19]. Similar results were observed in lettuce grown in the greenhouse [3]. These results suggest that light intensity and its quality has a strong impact on the accumulation of phenolic compounds in lettuce. In fact, it has been shown that high light intensity can enhance not only the total phenolic content but also the accumulation of chlorogenic acid and chicoric acid [20] [21]. While open field cultivation clearly enhanced the accumulation of many phenolic compounds, it also suppressed the accumulation of some flavonoids such as rutin and kaempferol in

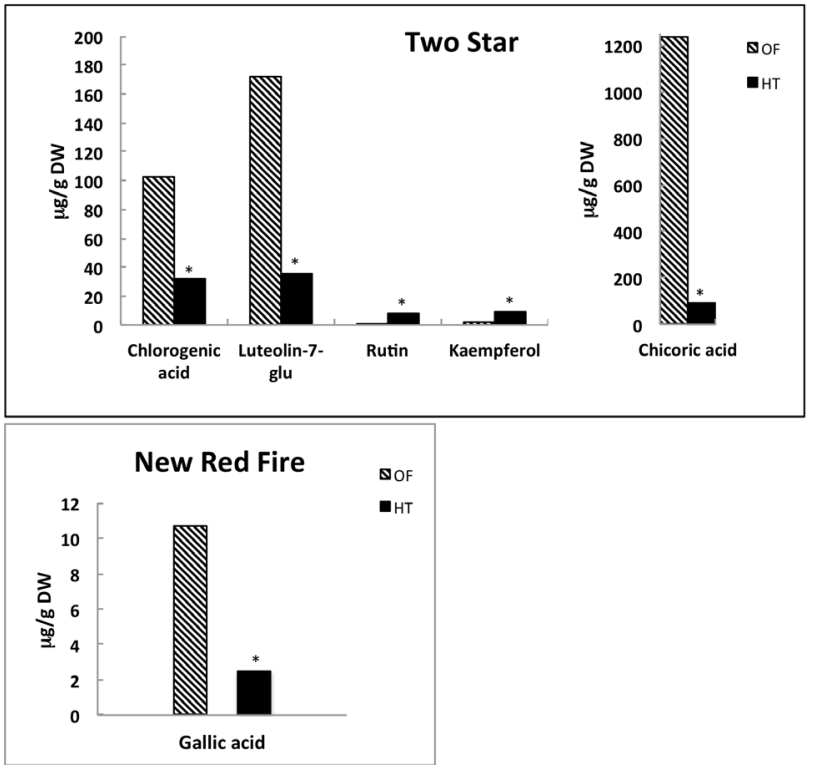

Figure 6. Phenolic compounds ( $\mu \mathrm{g} / \mathrm{g}$ dry weight) in leaves of "Two Star" and "New Red Fire" grown in open field and high tunnel. Significant difference between open field and high tunnel is indicated by ${ }^{*}$ at $\mathrm{p} \leq 0.05$. 
"Two Star" (Figure 6). However with regard to "New Red Fire", the only significant difference in phenolic compound accumulation was in gallic acid which accumulated 4-fold higher in plants grown in open field than in high tunnel.

Thus, overall these results suggest that high tunnel production has a greater impact on the nutritional quality in leafy vegetable like lettuce than in tomato fruits.

\section{Conclusion}

High tunnel environment had significant impact on the accumulations of major nutrients and health-promoting phytochemicals in both lettuce and tomato cultivars. While high tunnels provided better overall soil nutrient status and improved organic matter content they reduced the radiation level (PAR, UV-A and $\mathrm{UV}-\mathrm{B})$ received by the crops. Lettuce and tomato cultivars grown in high tunnel had higher $\mathrm{N}$ (protein) compared to those grown in open field. Lettuce grown in high tunnel also had higher concentrations of S and $\mathrm{Zn}$. However, high tunnel cultivation of lettuce suppressed the accumulation of many micronutrients such as $\mathrm{Mg}, \mathrm{Fe}, \mathrm{Cu}$ and $\mathrm{Mn}$ and many phenolic compounds including chlorogenic acid, chicoric acid and luteolin-7-glucoside. Overall, the changes in the nutrient status in response to high tunnel environment were more pronounced in lettuce than in tomato. The results suggest that high tunnel environment can significantly alter the nutritional characteristics of commonly consumed vegetables such as lettuce and tomato.

\section{Conflicts of Interest}

The authors declare no conflicts of interest regarding the publication of this paper.

\section{References}

[1] Zhao, X., Carey, E.E., Young, J.E., Wang, Q. and Iwamoto, T. (2007) Influences of Organic Fertilization, High Tunnel Environment, and Postharvest Storage on Phenolic Compounds in Lettuce. HortScience, 42, 71-76.

[2] Oh, M.M., Carey, E.E. and Rajashekar, C.B. (2011) Antioxidant Phytochemicals in Lettuce Grown in High Tunnels and Open Field. Horticulture, Environment, and Biotechnology, 52, 133-139. https://doi.org/10.1007/s13580-011-0200-y

[3] Romani, A., Pineli. P., Galardi, C., Sani, G., Cimato, A. and Heimler, D. (2002) Polyphenols in Greenhouse and Open-Air-Grown Lettuce. Food Chemistry, 79, 337-342. https://doi.org/10.1016/S0308-8146(02)00170-X

[4] Bradish, C.M., Yousef, G.G., Ma, G., Perkins-Veazie, P. and Fernandez, G.F. (2015) Anthocyanin, Carotenoid, Tocopherol, and Ellagitannin Content of Red Raspberry Cultivars Grown under Field or High Tunnel Cultivation in the Southeastern United States. Journal of the American Society for Horticultural Science, 140, 163-171.

[5] de Onis, M., Monteiro, C., Akre, J. and Clugston, G. (1993) The Worldwide Magnitude of Protein-Energy Malnutrition: An Overview from WHO Global Database on Child Growth. Bulletin of the World Health Organization, 71, 703-712.

[6] Wu, G., Fanzo, J., Miller, D.D., Pingali, P., Post, M., Steiner, J.L. and Thalack- 
er-Mercer, A.E. (2014) Production and Supply of High-Quality Food Protein for Human Consumption: Sustainability, Challenges, and Innovations. Annals of the New York Academy of Sciences, 1321, 1-19. https://doi.org/10.1111/nyas.12500

[7] United Nations, World Population Prospects (2015). https://esa.un.org/unpd/wpp/publications/files/key_findings_wpp_2015.pdf

[8] Bailey, R.L., West Jr., K.P. and Black, R.E. (2015) The Epidemiology of Global Micronutrient Deficiencies. Annals of Nutrition and Metabolism, 66, 22-33. https://doi.org/10.1159/000371618

[9] Ritchie, H. and Roser, M. (2018) Micronutrient Deficiency. OurWorldinData.org. http://ourworldindata.org/micronutrient-deficiency

[10] Fujihara, S., Kasuga, A. and Aoyagi, Y. (2001) Nitrogen-to-Protein Conversion Factors for Common Vegetables in Japan. Journal of Food Science, 66, 412-415. https://doi.org/10.1111/j.1365-2621.2001.tb16119.x

[11] Gieseking, J.E., Snider, H.J. and Getz, C.A. (1935) Destruction of Organic Matter in Plant Material by the Use of Nitric and Perchloric Acids. Industrial Engineering Chemistry Analytical Edition, 7, 185-186. https://doi.org/10.1021/ac50095a021

[12] Henchion, M., Hayes, M., Mullen, A.M., Fenelon, M. and Tiwari, B. (2017) Future Protein Supply and Demand: Strategies and Factors Influencing a Sustainable Equilibrium. Foods, 6, 1-21. https://doi.org/10.3390/foods6070053

[13] Wessells, K.R. and Brown, K.H. (2012) Estimating the Global Prevalence of Zinc Deficiency: Results Based on Zinc Availability in National Food Supplies and the Prevalence of Stunting. Public Library of Science One, 7, 1-11. https://doi.org/10.1371/journal.pone.0050568

[14] World Health Organization (WHO) (2001) Iron Deficiency Anaemia; Assessment, Prevention and Control: A Guide for Programme Managers. World Health Organization, Geneva, $114 \mathrm{p}$.

[15] Stoltzfus, R. (2003) Iron Deficiency: Global Prevalence and Consequences. Food and Nutrition Bulletin, 24, S99-S103. https://doi.org/10.1177/15648265030244S106

[16] Miller, J.L. (2013) Iron Deficiency Anemia: A Common and Curable Disease. Cold Spring Harbor Perspective in Medicine, 3, a011866.

https://doi.org/10.1101/cshperspect.a011866

[17] Fitzgerald, C.B. and Hutton, M. (2016) Soil Quality and Nutrient Levels in New and Established High Tunnels in Maine. Journal of the National Association of County Agricultural Agents, 9, No. 2.

[18] Knewtson, S.J.B., Kirkham, M.B., Janke, R.R., Murray, L.W. and Carey, E.E. (2012) Soil quality after Eight Years under High Tunnels. HortScience, 47, 1630-1633.

[19] Zhao, X., Iwamoto, T. and Carey, E.E. (2007) Antioxidant Capacity of Leafy Vegetables as Affected by High Tunnel Environment, Fertilization and Growth Stage. Journal of the Science of Food and Agriculture, 87, 2692-2699. https://doi.org/10.1002/jsfa.3032

[20] Oh, M.M., Carey, E.E. and Rajashekar, C.B. (2009) Environmental Stresses Induce Health-promoting Phytochemicals in Lettuce. Plant Physiology and Biochemistry, 47, 578-583. https://doi.org/10.1016/j.plaphy.2009.02.008

[21] Hipol, R.B. and Dionsio-Sese, M.L. (2014) Impact of Light Variation on the Antioxidant Properties of Red Lettuce. Electronic Journal of Biology, 10, 28-34. 